\title{
Does "Microteaching" Meet Pre-Service Teacher's Expectations?
}

\author{
Zinovia Masali \\ Marina Kougiourouki
}

\begin{abstract}
Practically every academic institution and official body that is involved in the preparation of teachers of every educational grade and orientation regarding didactic practice in class, has included "Microteaching" in its academic curriculum as a basic subject. However, what is the attitude of students themselves towards this subject? What are their expectations? Does it eventually meet these expectations? What kind of knowledge and skills does it provide them with? This current research attempts to give insight to such queries, as it aims at researching the views of 115 student teachers on the subject "Microteaching". These views have been documented in short texts that students were asked to produce both in the beginning of the academic semester-after receiving initial information - and in its end - after their training was completed. This study makes use of a double perspective: it focuses on the one hand on their expectations from this subject, while on the other on their critical overall assessment, in order to formulate a thorough and rounded picture regarding the subject "Microteaching" through the viewpoint of the students who are trained in it.
\end{abstract}

Keywords: teaching strategies, microteaching, elementary pre-service teacher education, teacher skills

\section{Introduction}

Every academic institution takes special care in studying and designing the curriculum to be attended by its prospective students, so that they become multilaterally trained in the required skills and knowledge and they are rendered qualified in exercising their future profession. More specifically, in Greece - but also worldwide - most university departments, as well as other education and training bodies that prepare future educators of every level and orientation on the educational practice in class, have included in their curriculum "Microteaching" as a fundamental subject (Fykaris \& Papaspyrou, 2014, McKnight, 1971).

"Microteaching" as a method of training future teachers has a long history (Allen, 1967, 1970) and a broad spectrum of applications (Dayanindhi \& Hegde, 2018, Chatzidimou, 2013). It is defined (Fortune et al., 1965, p. 389, Perlberg, 1987, p. 715) as the technique which can aid future teachers to exercise teaching skills either already gained or (even) new, in safe and simplified teaching conditions, keeping a distance from the environment of a natural class, which is complicated, full of unforeseen events and stressful to them. It is generally evaluated as a method of many advantages (Reddy, 2019, Chatzidimou, 1997), but this should not mean that certain negative parameters are not pointed out (Gibbs, 1980, Luaran et al., 2016). 
However, how is this subject regarded by the trainees themselves? What do they expect from it? Are their expectations finally met? What knowledge and skills are they provided with, in their opinion? Such are the queries attempted to be answered by this present research, whose aim is to investigate the views of 115 future educators on the "Microteaching" course, as these views have been illustrated in short texts that they were asked to write anonymously.

\section{Methodology}

The research was conducted among second-year students of the Department of Primary Education during the spring semester of the academic year 2018-2019. The subjects of the research were asked to write anonymously a short text in two-time phases: a) in the beginning of the academic semester, after receiving initial information regarding the practical Microteaching course and b) in the end of the academic semester, after having completed their practice using the Microteaching method. In the initial phase 115 texts were collected, while in the second 92.

To conduct this specific research, "content analysis" was considered to be the most appropriate method and was consequently used (Vamvoukas, 1988, Palla, 1992, Gall, Bory \& Gall, 1996). This is a technique that was initially developed in the US in the beginning of the previous century (Lazarsfeld, Berelson, \& Gaudet, 1948) and constitutes the most appropriate method for the objective and systematic description, processing and interpretation (qualitative and quantitative) of the denoted content of the communication whether in written or oral speech, as it allows for making replicable and valid inferences from texts to the contexts of their use (Berelson, 1952, Krippendorf, 2004).

This specific survey was conducted in the following stages:

Decoding: at this first stage, after careful and multiple readings of the students' texts, we decoded all the references related to the Microteaching course. For the decoding, the "topic" was chosen as an analysis and measurement unit. An "inference unit" (i.e. the text environment in which every subject is found) was defined to be a unit ranging from a word to an entire phrase. In total, 483 excerpts emerged from the first group of texts using this process, whereas for the second group 487 excerpts.

Choice of categories: after compiling the material and after careful and successive readings, the choice of categories was made on grounds of fulfilling the rules of objectivity, universality, thoroughness and mutual exclusion (Vamvoukas, 1991). The general categories which have emerged through restructuring of data (Papadopoulou, 2000) were coded (Bücker, 2020) as follows:

Chart 1. Categories - coding

\begin{tabular}{|l|l|}
\hline CATEGORY & CODE \\
\hline Microteaching course in the Department of Primary Education & A \\
\hline $\begin{array}{l}\text { The impact of Microteaching on the academic and professional course of } \\
\text { future teachers }\end{array}$ & B \\
\hline Acquisition of knowledge and skills through Microteaching & $\mathrm{C}$ \\
\hline
\end{tabular}


Categorisation: the next stage was the classification of references in categories. Care was taken so that each reference would be placed in only one category. The references that emerged from the decoding were finally distributed in the categories as follows:

\section{Chart 2. Distribution of references in categories}

\begin{tabular}{|c|c|c|c|c|c|}
\hline \multirow{2}{*}{ CATEGORY } & \multirow{2}{*}{ CODE } & \multicolumn{2}{|c|}{ Texts before practice in $\mathrm{M} / \mathrm{T}$} & \multicolumn{2}{|c|}{ Texts after practice in $\mathrm{M} / \mathrm{T}$} \\
\hline & & $\mathrm{N}$ & $\%$ & $\mathrm{~N}$ & $\%$ \\
\hline $\begin{array}{l}\text { Microteaching course in } \\
\text { the Department of } \\
\text { Primary Education }\end{array}$ & A & 150 & 31,06 & 173 & 35,52 \\
\hline $\begin{array}{l}\text { The impact of } \\
\text { Microteaching on the } \\
\text { academic and } \\
\text { professional course of } \\
\text { future teachers }\end{array}$ & B & 131 & 27,12 & 91 & 18,69 \\
\hline $\begin{array}{l}\text { Acquisition of knowledge } \\
\text { and skills through } \\
\text { Microteaching }\end{array}$ & C & 202 & 41,82 & 194 & 39,84 \\
\hline $\begin{array}{l}\text { Verification of } \\
\text { expectations on the } \\
\text { Microteaching course }\end{array}$ & D & - & - & 29 & 5,95 \\
\hline Total references & & 483 & 100 & 487 & 100 \\
\hline
\end{tabular}

\section{Analysis}

Through this categorization we subsequently attempt the quantitative analysis and processing of the material so that the statements of students regarding their expectations from the Microteaching course are approached and evaluated in the most comprehensive way.

In the first stage of the research 27 male future teachers $(23,5 \%)$ and 88 female future teachers $(76,5 \%)$ participated, while in the second stage the data was $21(22,8 \%)$ and $71(77,2 \%)$ respectively. What is, thus, observed is a female gender dominance, a common phenomenon for university departments that trains teachers, but also a decrease in the participation of students, which can be interpreted by the usual practice of attending more willingly in the beginning of the semester rather than in its end.

Assessing the percentages of the references in the above-mentioned categories (chart 2), we discover that the highest percentages for both groups of texts are gathered by the category that pertains to the knowledge and skills with which Microteaching provides its trainees. Following in second position - with a relatively small deviation, especially in the second text group - is the category of Microteaching as a subject in itself, while third position is held by the category regarding the impact of Microteaching on the academic and professional course

1 The category "Expectations" emerged only during the decoding of references in the texts that students wrote after their practice in Microteaching. 
of future teachers. Finally, concerning the second text group, the category related to verification of initial expectations, i.e. whether these were fulfilled or not, holds last position.

From the quantitative analysis of the separate thematic units, as well as their sub-categories (A-D), the following emerge:

Chart 3. Category A: The Microteaching course in the Department of Primary Education

\begin{tabular}{|l|l|l|l|l|l|}
\hline & & \multicolumn{2}{|l|}{$\begin{array}{l}\text { Texts before } \\
\text { practice in } \\
\text { Microteaching }\end{array}$} & \multicolumn{2}{c|}{$\begin{array}{l}\text { Texts after practice } \\
\text { in Microteaching }\end{array}$} \\
\hline $\begin{array}{l}\text { The Microteaching course in the } \\
\text { Department of Primary Education }\end{array}$ & $\mathrm{A}$ & $\mathrm{N}$ & $\%$ & $\mathrm{~N}$ & $\%$ \\
\hline Value of Microteaching course & $\mathrm{A} 1$ & 35 & 23,33 & 61 & 35,26 \\
\hline Microteaching as classroom simulation & $\mathrm{A} 2$ & 36 & 24,00 & 39 & 22,54 \\
\hline Opportunity for practice & $\mathrm{A} 3$ & 3 & 2,00 & 14 & 8,09 \\
\hline Potential for familiarization & $\mathrm{A} 4$ & 16 & 10,67 & 5 & 2,89 \\
\hline Acquaintance with the role of teacher & $\mathrm{A} 5$ & 17 & 11,33 & 9 & 5,20 \\
\hline Microteaching course as stressful & $\mathrm{A} 6$ & 5 & 3,33 & 3 & 1,73 \\
\hline $\begin{array}{l}\text { Acquaintance and interaction with fellow- } \\
\text { students }\end{array}$ & $\mathrm{A} 7$ & 38 & 25,33 & 42 & 24,28 \\
\hline Total references & & 150 & 100,00 & 173 & 100,00 \\
\hline
\end{tabular}

By analysing the thematic unit that pertains to the Microteaching course in the Department of Primary Education, we concluded that the relevant references can be divided in seven subcategories. It is worth mentioning that in both text groups the highest percentages of references (chart 3) are found in the same three sub-categories: "value of Microteaching course", "Microteaching as classroom simulation" and "Acquaintance and interaction with fellow-students". The only thing that differs is their ranking.

In the first text group, the highest percentage is held by the sub-category which collects student references on how important the course has been for them to get acquainted with their fellow-students, to cooperate with them, to interact and to contribute to each other's academic/professional evolution, while in the second text group it holds second position (chart 3). This can be possibly explained by the fact that during the first year of studies, future teachers mostly attend courses of general orientation in plenary, that is, they have not found themselves in smaller classes or groups that allow for dialogue, interaction, development of relationships and ties among them.

The sub-category that comes second in percentage of references in the first text group is the one whose references speak about the opportunity that future teachers had to experience the classroom for the first time, to participate in a simulation of school reality, while in the second text group it falls in third place (chart 3). A possible explanation for this-otherwise smallquantitative differentiation could be that the anticipation of the experience of Microteaching makes them assign it special value, which is slightly moderated when this has been fulfilled.

Third in percentage in the first text group comes the sub-category that refers to the value of the Microteaching course and which also collects the expectations and the evaluation of students for the course when still in its initial stages. This sub-category "shoots" in first place in the second text group (chart 3). It is highly likely that, the future teachers, having completed 
their practice in microteaching, have a complete overview on the course and therefore feel more comfortable and more at ease to assess it properly.

The sub-categories referring to the potential that Microteaching offers to practice skills, to familiarize oneself with teaching factors and to experience the role of teacher, alternate in the next positions in the students' texts in both groups, while the sub-category related to references characterizing the course as stressful, comes in last position. We could, therefore, cautiously reach the conclusion that future teachers draw such positive experiences from Microteaching that they manage to override any negative emotions of fear or stress that their "virgin" teaching session might bring, together with the subsequent critique from their fellowstudents and their professor.

Chart 4. Category B: Impact of Microteaching in professional teaching course

\begin{tabular}{|c|c|c|c|c|c|}
\hline & & \multicolumn{2}{|c|}{$\begin{array}{c}\text { Texts before } \\
\text { practice in M/T }\end{array}$} & \multicolumn{2}{c|}{$\begin{array}{c}\text { Texts after practice } \\
\text { in M/T }\end{array}$} \\
\hline $\begin{array}{c}\text { Impact of microteaching in professional } \\
\text { course as teacher }\end{array}$ & $\mathrm{B}$ & $\mathrm{N}$ & $\%$ & $\mathrm{~N}$ & $\%$ \\
\hline $\begin{array}{c}\text { Interesting and pleasant teaching } \\
\text { Effective teaching }\end{array}$ & $\mathrm{B} 1$ & 9 & 6,87 & 4 & 4,40 \\
\hline $\begin{array}{c}\text { Contribution in future academic and } \\
\text { professional course }\end{array}$ & $\mathrm{B} 3$ & 28 & 21,37 & 9 & 9,89 \\
\hline $\begin{array}{c}\text { Self-assessment and personal evolution } \\
\text { Acquisition of self-confidence and stress } \\
\text { management }\end{array}$ & $\mathrm{B} 4$ & 34 & 25,95 & 23 & 25,27 \\
\hline $\begin{array}{c}\text { Total references } \\
\quad\end{array}$ & 42 & 32,06 & 49 & 53,85 \\
\hline
\end{tabular}

When studying the thematic unit of references focusing on the impact of Microteaching on the future professional course of undergraduate students as teachers, we noted that in both text groups the sub-category that brings out the contribution of the course in causing the research subjects to gain self-confidence and manage their stress effectively collects the highest percentage in references (chart 4). Moreover, we observe that in subsequent texts this percentage has significantly increased, clearly displaying that the experience in Microteaching has seriously boosted future teachers' confidence in their own powers and has helped them overcome -in part - their stress and anxiety in the face of the teaching procedure. Second position is held - equally before and after their practice in microteaching -by the sub-category that refers to the course contribution towards their self-assessment, recognition of their mistakes and personal development related to teaching actual students, with almost similar percentages (chart 4). Following in next place in both text groups is the sub-category on the contribution of this course in the academic and professional course of future teachers. It is, however, worth noting that in this case, the percentages show a great discrepancy, evidently surging - as it happens with the other categories - towards the sub-category that collects references on subjects' forming a positive self-image thanks to Microteaching. In the last positions of the thematic unit one finds the sub-categories that speak about the success of an effective and interesting/pleasant teaching with the aid of Microteaching bearing similar percentages (chart 4). 
Chart 5. Category C: the contribution of Microteaching in skills and knowledge acquisition

\begin{tabular}{|c|c|c|c|c|c|c|}
\hline \multicolumn{7}{|c|}{ Texts before practice in Microteaching } \\
\hline $\begin{array}{l}\text { SKILLS/KNOWLEDGE } \\
\text { ACQUISITION }\end{array}$ & C & $\mathrm{N}$ & $\%$ & $\mathrm{~N}$ & $\%$ & $\begin{array}{l}\% \text { of } \\
\text { total }\end{array}$ \\
\hline COGNITIVE LEVEL & C1 & 51 & 25,25 & & & \\
\hline ICT & $\mathrm{C} 1 \mathrm{~A}$ & & & 13 & 25,49 & 6,44 \\
\hline \multirow[t]{2}{*}{ Knowledge and skills } & C1B & & & 38 & 74,51 & 18,81 \\
\hline & & & & & 100,00 & \\
\hline $\begin{array}{l}\text { TEACHING } \\
\text { METHODOLOGY }\end{array}$ & $\mathrm{C} 2$ & 94 & 46,53 & & & \\
\hline $\begin{array}{l}\text { Organizing and Planning a } \\
\text { Session }\end{array}$ & $\mathrm{C} 2 \mathrm{~A}$ & & & 35 & 37,23 & 17,33 \\
\hline Teaching Preparation & C2B & & & 9 & 9,57 & 4,46 \\
\hline Time Management & $\mathrm{C} 2 \mathrm{C}$ & & & 10 & 10,64 & 4,95 \\
\hline $\begin{array}{l}\text { Methodology and Teaching } \\
\text { Principles }\end{array}$ & C2D & & & 10 & 10,64 & 4,95 \\
\hline Teaching Means & $\mathrm{C} 2 \mathrm{E}$ & & & 7 & 7,45 & 3,47 \\
\hline Teaching Implementation & $\mathrm{C} 2 \mathrm{~F}$ & & & 0 & 0,00 & 0,00 \\
\hline \multirow[t]{2}{*}{$\begin{array}{l}\text { Teaching Models and } \\
\text { Techniques }\end{array}$} & $\mathrm{C} 2 \mathrm{G}$ & & & 23 & 24,47 & 11,39 \\
\hline & & & & & 100,00 & \\
\hline PEDAGOGIC HANDLINGS & C3 & 57 & 28,22 & & & \\
\hline $\begin{array}{l}\text { Mistakes and queries' } \\
\text { management }\end{array}$ & C3A & & & 11 & 19,30 & 5,45 \\
\hline $\begin{array}{l}\text { Pedagogic atmosphere and } \\
\text { Class management }\end{array}$ & C3B & & & 36 & 63,16 & 17,82 \\
\hline $\begin{array}{l}\text { Movement and Body } \\
\text { Posture }\end{array}$ & $\mathrm{C} 3 \mathrm{C}$ & & & 6 & 10,53 & 2,97 \\
\hline \multirow[t]{2}{*}{ Teaching Style and Poise } & C3D & & & 4 & 7,02 & 1,98 \\
\hline & & & & & 100 & \\
\hline Total references & & 202 & 100 & 202 & & 100,00 \\
\hline \multicolumn{7}{|c|}{ Texts after practice in Microteaching } \\
\hline $\begin{array}{l}\text { SKILLS/KNOWLEDGE } \\
\text { ACQUISITION }\end{array}$ & $C$ & & $\%$ & & $\%$ & $\begin{array}{l}\% \text { of } \\
\text { total }\end{array}$ \\
\hline COGNITIVE LEVEL & $\mathrm{C} 1$ & 54 & 27,84 & & & \\
\hline ICT & C1A & & & 13 & 24,07 & 6,70 \\
\hline \multirow[t]{2}{*}{ Knowledge and skills } & C1B & & & 41 & 75,93 & 21,13 \\
\hline & & & & & 100 & \\
\hline $\begin{array}{l}\text { TEACHING } \\
\text { METHODOLOGY }\end{array}$ & $\mathrm{C} 2$ & 100 & 51,55 & & & \\
\hline $\begin{array}{l}\text { Organizing and Planning a } \\
\text { Session }\end{array}$ & $\mathrm{C} 2 \mathrm{~A}$ & & & 68 & 68 & 35,05 \\
\hline
\end{tabular}




\begin{tabular}{|l|l|l|l|l|l|l|}
\hline Teaching Preparation & C2B & & & 14 & 14 & 7,22 \\
\hline Time Management & C2C & & & 5 & 5 & 2,58 \\
\hline $\begin{array}{l}\text { Methodology and Teaching } \\
\text { Principles }\end{array}$ & C2D & & & 2 & 2 & 1,03 \\
\hline Teaching Means & C2E & & & 1 & 1 & 0,52 \\
\hline Teaching Implementation & C2F & & & 6 & 6 & 3,09 \\
\hline $\begin{array}{l}\text { Teaching Models and } \\
\text { Techniques }\end{array}$ & C2G & & & 4 & 4 & 2,06 \\
\hline PEDAGOGIC HANDLINGS & C3 & 40 & 20,62 & & & \\
\hline $\begin{array}{l}\text { Mistakes and queries' } \\
\text { management }\end{array}$ & C3A & & & 2 & 5 & 1,03 \\
\hline $\begin{array}{l}\text { Pedagogic atmosphere and } \\
\text { Class management }\end{array}$ & C3B & & & 30 & 75 & 15,46 \\
\hline $\begin{array}{l}\text { Movement and Body } \\
\text { Posture }\end{array}$ & C3C & & & 8 & 20 & 4,12 \\
\hline Teaching Style and Poise & C3D & & & 0 & 0 & 0,00 \\
\hline & & 194 & 100 & 194 & & 100,00 \\
\hline Total references & & & & & \\
\hline
\end{tabular}

The first thematic unit which collects students' comments on knowledge acquisition and skills owing to the Microteaching course, offers rich material for analysis. This rich material is distributed in three separate sub-units and they, in turn, in other sub-categories. First position (chart 5) in both text groups is held by the sub-unit that concerns the acquisition of Teaching Methodology knowledge and skills, in which Microteaching trains future teachers $(46,53 \mathrm{k \alpha} \mathrm{L}$ $51,55 \%)$. The other two categories alternate for second and third position: in the first text group, the sub-unit that talks about learning pedagogic handlings is preceding $(28,22 \%)$, whereas in the second group the sub-unit that refers to the enrichment of cognitive background of students is preceding $(27,84 \%)$. It is obvious that the subjects of this research anticipate to delve into topics of Teaching Methodology and assess this delving as the basic benefit to be gained from this course. Moreover, they initially wish to get acquainted with various pedagogic handlings which will help them in the educational process, but eventually seem to appreciate more the enrichment of their cognitive "gear", possibly because they understand that their instruction in issues of Teaching Methodology fortifies them also in the level of pedagogic handling of their students.

Upon examination of the separate categories of the sub-units (chart 5), it can be observed that:

In the sub-unit "Skills and knowledge acquisition", the reference to "skills and knowledge"

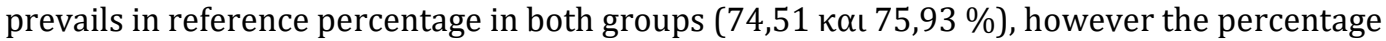
of references that depicts student expectation to train in ICT is not negligible (25,49\%), nor is the certainty that this has been achieved $(24,07 \%)$, a remarkable fact for a course of nontechnical orientation.

In the sub-unit "Teaching Methodology", the references on training in course planning and organization prevail in percentage (68\%), proving the importance that students place in this factor of the educational process, both before the start of the Microteaching $(37,23 \%)$ and especially after its end (68\%), when they have been convinced of its crucial role. In the first 
text group, what follows in second position is the references on expectation to learn models and techniques for teaching $(24,47 \%)$, while the references on practicing in time management and training in methodology and teaching principles tie for third place $(10,64 \%)$. In the second text group, in second position we encounter the references on teaching preparation (14\%), and in third place references on teaching implementation $(6 \%)^{1}$. Besides the shift in topics which students refer to after the implementation of Microteaching, it is also worth noting the exceptionally low percentage that these two categories share, compared to the corresponding in the first group. This perhaps reveals the different estimation of teaching factors on behalf of the research subjects after their classroom experience.

In the sub-unit "Pedagogic Handling", prevalent in percentage in both text groups are the references on skills that contribute to pedagogic atmosphere and class management $(63,16$ and $75 \%$ ), whereas second position is held in the first text group by references on mistake and student query management skills $(19,3 \%)$, while in the second group by those one teacher's choice of movement inside the classroom and proper body posture when teaching (20\%), leaving thus in last position - in both cases - the references on style and teaching poise. It is rendered obvious that students are concerned and stressed about their coexistence with pupils in class as well as the appropriate ways to maintain a healthy and beneficial to them pedagogic atmosphere.

In attempting an analysis of the separate categories at the level of percentage within the broader thematic unit (Skills and knowledge acquisition), we discover an entirely different distribution between the two text groups. The sub-category that pertains to the skills and knowledge that microteaching cultivates in the first group holds first place with a percentage of $18,81 \%$, while in the second group it falls second $(21,13 \%)$. Following comes in the first group the sub-category referring to pedagogic atmosphere and class management $(17,82 \%)$, which ranks third in the second group (15,46\%). Finally, in the first group, what comes after is the sub-category on planning and organizing a session (17,33\%), which in the second group scores the highest percentage of references $(35,05 \%)$. This reversal possibly reflects the change in views and attitudes that practice through Microteaching has brought about, and the subsequent shift of attention of students from a theoretical address to teaching towards a more practical and technical approach to it.

\section{Chart 6: Category D: Expectations from the Microteaching course}

\begin{tabular}{|l|l|l|l|}
\hline Texts after practice in M/T & D & N & $\%$ \\
\hline EXPECTATIONS & D1 & 21 & 72,41 \\
\hline Verification of expectations & D2 & 8 & 27,59 \\
\hline Falsification of expectations & & 29 & 100 \\
\hline Total references & & \\
\hline
\end{tabular}

Only in the second text group do we find - as would be expected - references which discuss either the anticipated or the non-confirmed expectations that had been formulated and had perhaps - been noted in initial texts by the subjects of the research in the beginning of the academic semester. The greatest part $(72,41 \%)$ is occupied by the sub-category with references that speak about verification of initial positive expectations, while the sub-category

1 This sub-category had zero percentage in the first text group. 
bearing references that inform us on refutation) of initial expectations comes after with a percentage of $27,59 \%$, whether these (refutation) appear in a negative, or positive way, enhancing thus the positive value that is attributed to the Microteaching course (chart 6).

\section{Discussion and Conclusions}

The quantitative display of the content analysis of the texts that students wrote as much in the beginning of the academic semester, before practicing in Microteaching, as after its completion, is revealing of the expectations they had from this course, but also of what they finally gained from it.

By prioritizing among their expectations from the Microteaching course, as well as its subsequent evaluation, the acquisition of knowledge and skills, they express their positive attitude towards their studies and their effort to qualify themselves on many aspects, so that in the future they will be able to live up to the demands of the teaching profession (Parylo et al., 2015, Ilie, 2015).

This is the reason why, when speaking a posteriori about this specific course in the Department of Primary Education, they mainly refer to its gravity and usefulness in the framework of the curriculum of the Department where they study (Deniz, 2010), when initially they had considered as most important benefit the opportunity it gave them to socialize with fellow students they did not know up to that time.

An important success of the Microteaching course is considered to be its contribution to the boosting of their self-confidence, as well as their stress management related to teaching before an audience, something that seemed to be of special concern to them from the very start, related to their future educational course, as it appears in their initial texts. Moreover, they emphatically claim - as much before as after the course - that the specific course helps them to get better acquainted with their own potential and to improve any weaknesses they may have, so that they evolve into efficient educators (Saban \& Çoklar, 2013, Elias, 2018).

At the level of course content, future teachers steadily consider as fundamental contributor to the value of Microteaching, skills in which they train in the framework of their practical exercises, such as planning, organizing and implementation of teaching, utilizing relevant principles and means, time management etc. That is to say, teaching methodology seems to bear gravity for their pedagogic training in general (Mahmud \& Rawshon, 2013).

To summarise, the future teachers of the Department of Primary Education view the Microteaching course from the start as a promising course that will provide them with the opportunity to develop academically on the one hand, and professionally on the other, but that will also broaden their horizons and their potential in the implementation of a teaching session. This view is verified to a great extent and thus the Microteaching course proves to be a catalytic factor for the exercise of their educational work (Kougiourouki, 2003, 2013).

The above conclusions allow us to highlight - as many have done before us - how important it is for this course to be included in the curricula of all academic departments/schools and bodies that prepare educators and trainers of all grades and orientations, even in digital form (Ledger \& Fischetti, 2016). The Microteaching course is almost always considered worthy in the conscience of future teachers and constitutes an experience that remains indelibly imprinted in their conscience. 


\section{References}

[1] Allen, D. W., \& Cooper, J. M. (1970). Microteaching. PREP-17. Distributed by ERIC Clearinghouse. Washington, D.C.

[2] Allen, D. W., \& Stanford Univ., CA. (1967). Micro-teaching, a description. [Washington, D.C.]: Distributed by ERIC Clearinghouse. Retrieved from: https://eric.ed.gov/?id=ED019224

[3] Berelson, B. (1952). Content analysis in communication research. Michigan: Free Press.

[4] Bücker, N. (2020). How to Code Your Qualitative Data-A Comparison Between Grounded Theory Methodology and Qualitative Content Analysis. Forum Qualitative Sozialforschung / Forum: Qualitative Social Research, 21(1). http://dx.doi.org/10.17169/fqs-21.1.3389

[5] Chatzidimou, D. (1997). Micro-teaching in teacher education. A theoretical and empirical approach. Thessaloniki: Kyriakidis Bros.

[6] Chatzidimou, K. (2013). Microteaching in Teacher Education through the Students' Perspective. In: P.M. Pumilia-Gnarini, E. Favaron, E. Pacetti, J. Bishop \& L. Guerra (eds.), Handbook of Research on Didactic Strategies and Technologies for Education: Incorporating Advancements. Vol. II. (pp. 620-631). Hershey PA: IGI Global.

[7] Dayanindhi, V. K., \& Hegde, S. P. (2018). Effectiveness of microteaching as a method of developing teaching competence among in-service medical teachers. Journal of advances in medical education \& professionalism, 6(4), 155-161.

[8] Deniz, S. (2010). Implications of Training Student Teachers of Preschooling through Micro-Teaching Activities for a Classroom with Mentally-Disabled Students, Educational Research and Reviews, 5(6), 338-346. Retrieved from: https://academicjournals.org/journal/ERR/article-full-text-pdf/E1695C74092

[9] Elias, S.K. (2018). Pre-Service Teachers' Approaches to the Effectiveness of MicroTeaching in Teaching Practice Programs. Open Journal of Social Sciences, 6, 205-224. https://doi.org/10.4236/jss.2018.65016

[10] Fortune, J. C., Cooper, J. M., \& Allen, D. W. (1967). The Stanford Summer MicroTeaching Clinic, 1965. Journal of Teacher Education, 18(4), 389-393. https://doi.org/10.1177/002248716701800402

[11] Fykaris, I., \& Papaspyrou, G. (2014). Intertemporal evolution and structural meaning of "microteaching" in the didactic functionality of the Pedagogic Departments of Greece. In: Proceedings of the $7^{\text {th }}$ Scientific Conference of History of Education with International Participation: Which knowledge has the highest value? HistoricalComparative Approaches. Retrieved from: https://eriande-elemedu.emillescreations.com/art/uploads/prgrammata_anoteras2.pdf

[12] Gall, M. D., Borg, W. R., \& Gall, J. P. (19966). Educational research: An introduction. White Plains, N.Y: Longman Publishers USA.

[13] Gibbs, I. (1980). Initial Caution among Students towards Micro-teaching. Research in Education, 24(1), 45-56. https://doi.org/10.1177/003452378002400104

[14] Ilie, V. (2015). Attitude towards pedagogical and methodological training and development - a comparative analysis. Procedia - Social and Behavioral Sciences, 180, 820-827. https://doi.org/10.1016/j.sbspro.2015.02.217

[15] Kougiourouki, M. (2003). The role of Microteaching in the framework of teachers' Education and Training. Thessaloniki: Kiriakidis Bros.

[16] Kougiourouki, M. (2013). The contribution of microteaching in the teaching readiness of the educator: students' views. In: M. Kougiourouki, P. Stravakou, \& K. Chatzidimou 
(eds.), Pedagogic and teaching research studies. Honorary tribute to professor Eleni Ev. Taratori-Tsalkatidou (pp. 143-162). Thessaloniki: Kiriakidis bros publishing house.

[17] Krippendorff, K. (20042nd). Content analysis. An introduction to its methodology. London: Sage.

[18] Lazarsfeld, P., Berelson, B., \& Gaudet, H. (1948). The people's choice. New York: Columbia University Press.

[19] Ledger, S., \& Fischetti, J. (2020). Micro-teaching 2.0: Technology as the classroom. Australasian Journal of Educational Technology, 36(1), 37-54. Retrieved from: https://ajet.org.au/index.php/AJET/article/view/4561/1603

[20] Luaran, J.E., Rom, K.B.M., \& Jain J. (2016) Attitude on Microteaching: A Study on Third and Fourth Year Science Student Teachers of the Faculty of Education, UiTM. In: C. Fook, G. Sidhu, S. Narasuman, L. Fong, S. Abdul Rahman (eds.), 7th International Conference on University Learning and Teaching (InCULT 2014) Proceedings. Springer, Singapore. https://doi.org/10.1007/978-981-287-664-5_5

[21] Mahmud, I., \& Rawshon, S. (2013). Micro Teaching to Improve Teaching Method: An Analysis on Students' Perspectives. IOSR Journal of Research \& Method in Education, 1, 69-76. https://doi.org/10.9790/7388-0146976

[22] Mcknight, P. C. (1971). Microteaching in Teacher Training. Research in Education, 6(1), 24-38. https://doi.org/10.1177/003452377100600103

[23] Palla M. (1992). Content analysis. Philologos, 67, 45-54.

[24] Papadopoulou, Ch. (2000). Qualitative data analysis in educational research. Makednon, 7, 143-155.

[25] Parylo, O., Süngü, H., \& Ilgan, A. (2015). Connecting Attitudes Toward Teaching and Pedagogical Formation Courses: A Study of Turkish Pre-Service Teachers. Australian Journal of Teacher Education, 40(5). Retrieved from: http://ro.ecu.edu.au/ajte/vol40/iss5/5

[26] Perlberg, A. (1987). Microteaching: Conceptual and Theoretical Bases. In: M. J. Dunkin (ed.), The International encyclopedia of teaching and teacher education (pp. 715720). Oxford [Oxfordshire]; New York: Pergamon Press.

[27] Reddy, K. (2019). Teaching How to Teach: Microteaching (A Way to Build up Teaching Skills). Journal of Gandaki Medical College-Nepal, 12(1), 65-71. https://doi.org/10.3126/jgmcn.v12i1.22621

[28] Saban, A. \& Çoklar, A. N. (2013). Pre-Service Micro -Teaching Method in Teaching Practice Classes. The Turkish Online Journal of Educational Technology, 12(2), 234240. Retrieved from: https://files.eric.ed.gov/fulltext/EJ1015454.pdf

[29] Vamvoukas, M. (19912). Introduction in psychopedagogic research and methodology. Athens: Grigoris. 